\title{
Newly discovered eastern dispersal of the youngest Toba Tuff
}

\author{
S.-R. Song ${ }^{\mathrm{a}, *}$, C.-H. Chen ${ }^{\mathrm{b}}$, M.-Y. Lee ${ }^{\mathrm{a}}$, T.F. Yang ${ }^{\mathrm{a}}$, Y. Iizuka ${ }^{\mathrm{b}}$, K.-Y. Wei ${ }^{\mathrm{a}}$ \\ anstitute of Geology, National Taiwan University, 245 Chousan Road, Taipei 106-17, Taiwan, ROC \\ ${ }^{\mathrm{b}}$ Institute of Earth Sciences, Academia Sinica, P.O. Box 1-55, Nankang, Taipei, Taiwan, ROC
}

Received 25 January 2000; accepted 17 March 2000

\begin{abstract}
Volcanic glasses with minor mafic mineral fragments, such as biotite and hornblende, found in deep-sea sediments of the South China Sea Basin (SCSB) have been clearly identified as eruptive products of the Youngest Toba Tuff (YTT), northern Sumatra, Indonesia. The tephra layer occurs between marine oxygen isotopic event 5.1 (79.3 ka) and event $4.22(64.1 \mathrm{ka})$, with an interpolated age of $74.0 \mathrm{ka}$, which is in good consistence with previous radiometric dating (73-75 ka) and ice-core dating $(71 \pm 5 \mathrm{ka})$ of the YTT. The tephra consists predominantly of bubble-wall shards with minor elongated vesicles of pumice fragments. Geochemical characteristics of the tephra, such as high total alkali content, high ${ }^{87} \mathrm{Sr} /{ }^{86} \mathrm{Sr}$ ratio and uniformity of their compositions, all suggest that the recovered tephra is of the Youngest Toba Tuff. This finding supports an extended dispersal of coarse $(>63 \mu \mathrm{m})$ glass shards over $1500 \mathrm{~km}$ northeast of the Toba caldera, a direction opposite to what previously conceived. While providing a better documentation of the distribution extent of the Toba ash, this report points to the need to reestimating the eruptive volume of the YTT and re-evaluating its environmental impact. (C) 2000 Elsevier Science B.V. All rights reserved.
\end{abstract}

Keywords: Tephra; Youngest Toba Tuff; South China Sea Basin; Glass geochemistry

\section{Introduction}

Until just recently, pumice clasts, tephra beds and dispersed glass shards found in the Quaternary deepsea sediments of the South China Sea Basin (SCSB) have generally been considered to be from the east, i.e. the Luzon and Bicol arc volcanoes in the Philippines (Yang and Fan, 1990; Wang et al., 1992; Wiesner et al., 1995), because the prevalent winds around the equator $\left( \pm 15^{\circ}\right.$ of the equator) are westward (Kennett, 1981). Accordingly, most of the tephra reported from the western Indonesian and Philippine arcs is distributed farther to the west (Ninkovich,

\footnotetext{
* Corresponding author. Tel.: + 886-2-23630231, ext. 2671; fax: $+886-2-23636095$.

E-mail address: srsong@ccms.ntu.edu.tw (S.-R. Song).
}

1979; Wiesner et al., 1995). Although potential sources of tephra in the SCSB may also be in the south, the Indonesian arc volcanoes and the local intra-basinal submarine volcanoes of the SCSB, no previous geochemical data of the dispersed glass shards have identified such a source.

The Toba caldera in northern Sumatra, Indonesia erupted at least three major rhyolitic tuffs during the Quaternary, named the Oldest Toba Tuff (OYY), the Middle Toba Tuff (MTT) and the Youngest Toba Tuff (YTT) (Chesner and Rose, 1991). The mean ${ }^{40} \mathrm{Ar} /{ }^{39} \mathrm{Ar}$ ages of these are 840,000 $\pm 30,000,501,000 \pm$ 5,000 , and 73,000 $\pm 4,000 \mathrm{yr}$, respectively (Diehl et al., 1987; Chesner and Rose, 1991). It is well known that the eruption of the YTT produced an extensive blanket of co-ignimbritic ash covering such wide areas as the Indian Ocean and Continent. 


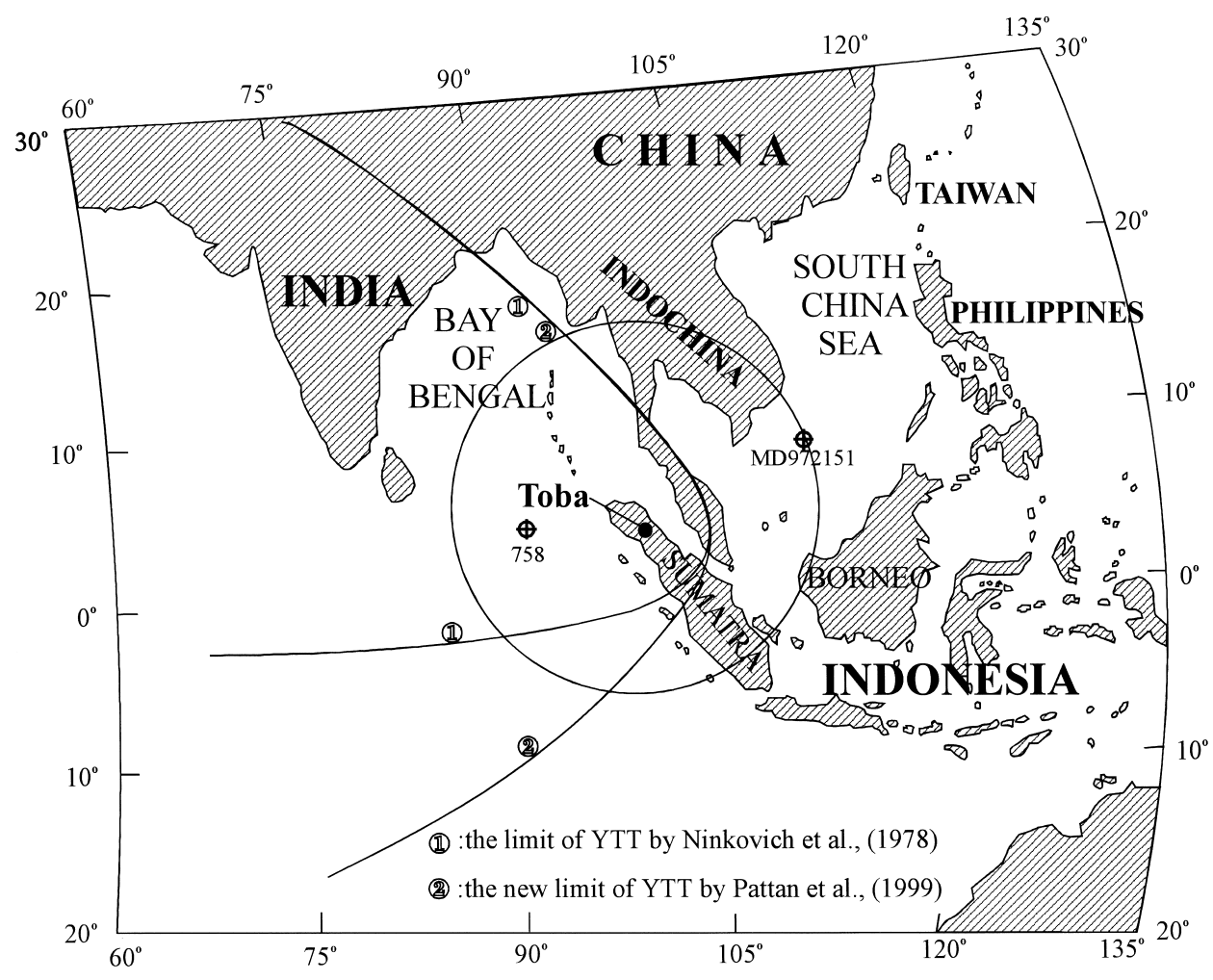

Fig. 1. Map of the South China Sea, Indonesian arc and adjacent areas showing the location of the studied core MD972151 and ODP core 758. The radius of the circle is $1500 \mathrm{~km}$. The solid line "(1)" indicates the distribution of the YTT tephra (Ninkovich et al., 1978). The solid line "2" indicates the recent results of the YTT fallout zone in the Southern Hemisphere by Pattan et al. (1999).

The eruption of the YTT at ca. 73,000 years ago is believed to have been one of the Earth's largest rhyolitic eruptions in the Quaternary. It erupted ca. 2500$3000 \mathrm{~km}^{3}$ of dense-rock-equivalent pyroclastic materials and produced widespread fallout tephra (Rose and Chesner, 1987) throughout Malaysia, the Bay of Bengal, the Indian Ocean Basin north of the equator (Fig. 1) (Ninkovich, 1979; Dehn et al., 1991) and over much of the Indian subcontinent (Shane et al., 1995). It was believed that it extended just over $3000 \mathrm{~km}$ from the source. However, a relatively new occurrence of the YTT in abyssal sediments of the Central Indian Basin south of the equator has also been identified (Pattan et al., 1999). It extends the distribution of coarse glass shards some $1500 \mathrm{~km}$ south of the previously known fallout zone (Fig. 1) (Patten et al., 1999) and probably increases the previously estimated volume of the YTT. All earlier studies had only shown that the main distribution of the tephra of the YTT was only to the west, northwest and southwest of northern Sumatra, Indonesia.

It was reported that the YTT produced and injected huge amounts of tephra and aerosols into the stratosphere, which may have had a severe impact on the Earth's climate. Therefore, the YTT eruption had even been considered by some researchers as the trigger of the volcanic winter and last glaciation (Rampino and Self, 1992, 1993). In fact, however, ice-core records have since indicated that the YTT eruption occurred prior to a short-lived stadial (1 ka) during a fluctuating climate and not at the beginning of the major glaciation at ca. $67.5 \mathrm{ka}$ (Zielinski et al., 1996).

A giant piston core, MD972151, was obtained during Leg II of the International Marine Past Global Changes Study (IMAGES) III Cruise in June 1997 in the southern SCSB (Chen et al., 1998). The total recovered length was $26.72 \mathrm{~m}$. A tephra-rich bed at 


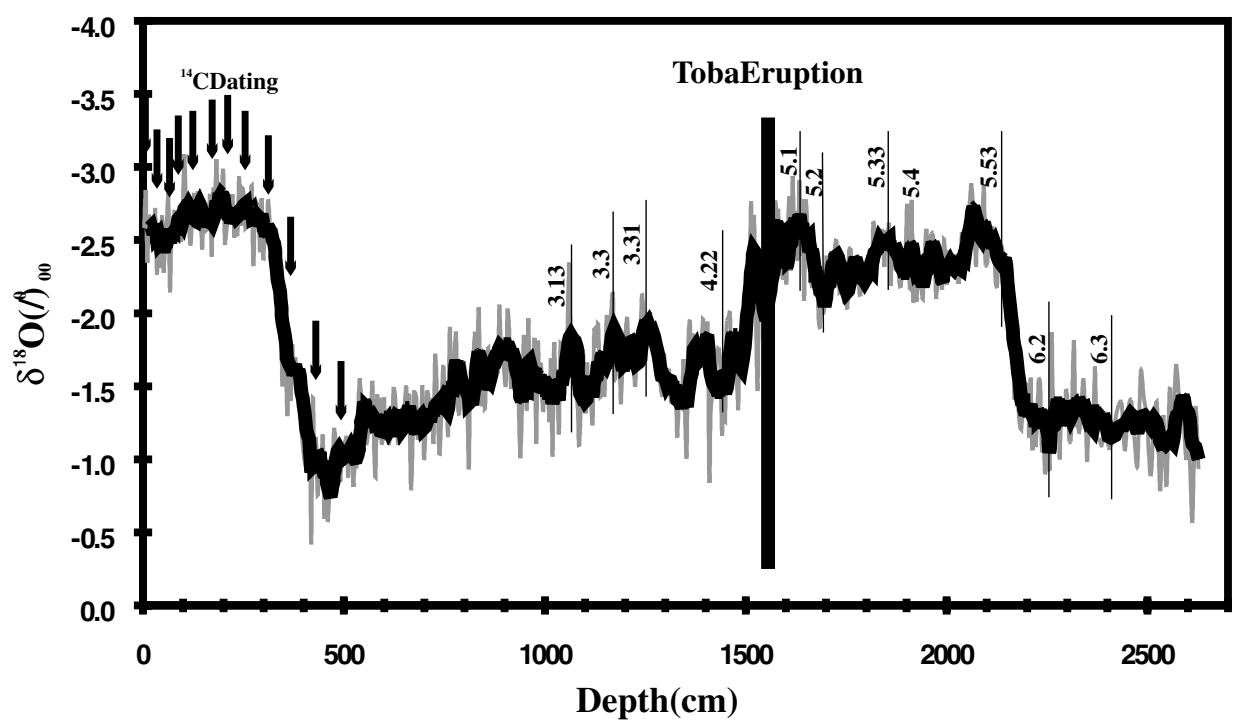

Fig. 2. Time-series of $\delta{ }^{18} \mathrm{O}$ of surface-dwelling planktic foraminifera G. sacculifer from MD972151, plotted against depth in core. The bold vertical line indicates the interval of Toba glass shards. Vertical arrows mark 12 AMS radiocarbon dates. Digital numbers represent various oxygen isotopic events correlated to the standard marine isotopic record of SPECMAP stack.

$15.58 \mathrm{~m}$ was found, and it contained abundant coarse glass shards and biotite crystals $(>63 \mu \mathrm{m})$.

This paper presents the results of glass shard morphology, mineral chemistry as well as the major, trace and $\mathrm{Sr}$-isotopic compositions of the glasses. Comparisons are made with the published high-resolution oxygen isotope stratigraphy to constrain the eruptive age of this tephra layer and to correlate it to its source, the YTT of the Toba caldera, Sumatra, Indonesia. The data show the tephra distribution of the YTT extending $1500 \mathrm{~km}$ to the northeast of the Toba caldera, which is yet another direction that must be included with the previously known zones. Such a wide distribution helps to understand better the dispersal of the ash cloud and to evaluate the global impact of such a mega-eruption.

\section{Samples and methods}

During Leg II of the IMAGES III Cruise, core MD972151 was raised from the northern slope of the Wan-An Shallow $\left(8^{\circ} 43.73^{\prime} \mathrm{N}, 109^{\circ} 52.17^{\prime} \mathrm{E}\right)$ off southeastern Vietnam at a water depth of $1550 \mathrm{~m}$ (Fig. 1). The core consisted predominantly of dark gray hemipelagic sediments. No volcanic layers were detected visually. Samples were taken every $4 \mathrm{~cm}$ down to $24.0 \mathrm{~m}$ and then every $8 \mathrm{~cm}$ down the lower section to the bottom for the purpose of high resolution oxygen isotope stratigraphy (Lee et al., 1999a). The results show that core MD972151 provides a continuous record from 153 to $0.94 \mathrm{ka}$, with the sedimentation rate varying from 5.6 to $78 \mathrm{~cm} / \mathrm{ka}$ and a temporal resolution of isotopic record about $60-150$ and 250 years per sample for the upper and lower parts of the core, respectively (Lee et al., 1999a).

Abundant glass shards with minor mafic minerals were first found in the interval at depth $15.58 \mathrm{~m}$, as manifested by the highest peak abundance of coarse grains $(>63 \mu \mathrm{m})$ throughout the core (Lee et al., 1999a). The depth of $15.58 \mathrm{~m}$ is located between the oxygen isotopic events $5.1(79.3 \mathrm{ka})$ and 4.22 (64.1 ka) (Fig. 2). It falls within the range of the radiometric dates of the Toba deposits, 73,00075,000 years BP (Ninkovich et al., 1978; Chesner and Rose, 1991), or the ice-core age dated, 71,000 \pm 5000 years B.P. (Zielinski et al., 1996). The present authors returned to check the core at the depth around $15.58 \mathrm{~m}$ and a tephra layer of about $2 \mathrm{~cm}$ was found at the $15.63 \mathrm{~m}$ depth. This layer was predominantly composed of colorless glass shards with trace amounts 


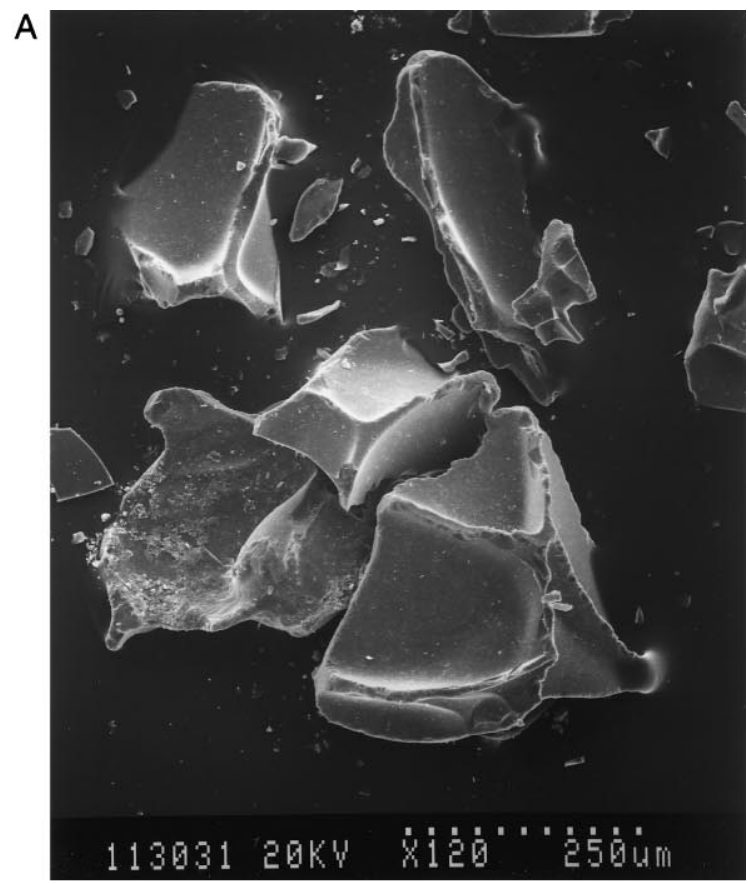

B

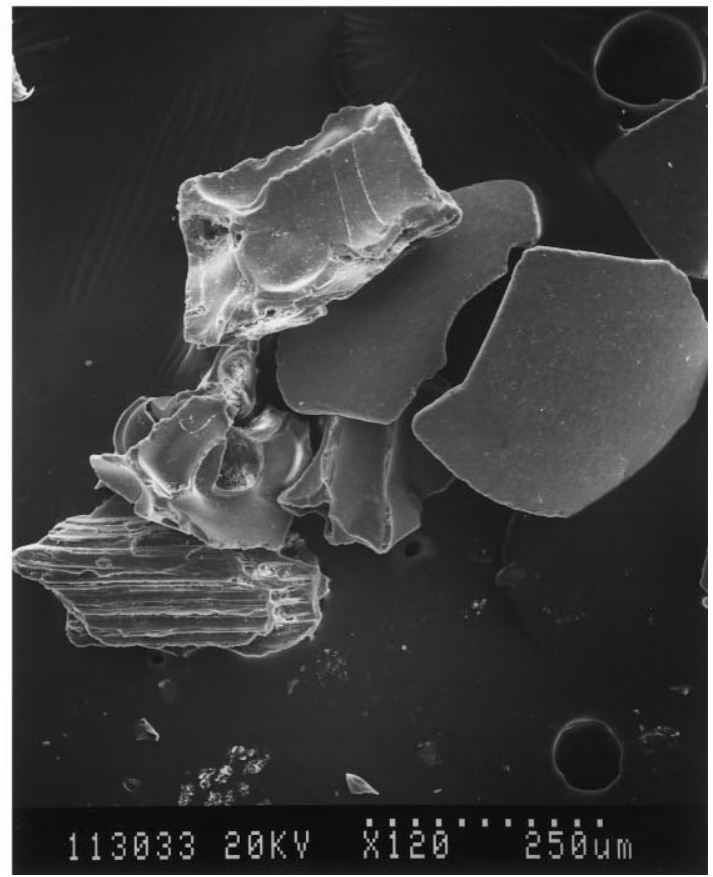

Fig. 3. SEM photomicrographs of tephra from core MD972151 in the SCSB. (A) Blocky and angular shards showing normal to elongated vesicles with smooth and conchoidal fractured surface. (B) Bubble-wall shards showing smooth and slightly curved surface. Pumiceous shards showing elongated and parallel vesicles. The length dot line on the bottom shows $250 \mu \mathrm{m}$. of dark subhedral biotite and rarer hornblende crystal. The gradational contacts of the tephra layer with host sediments in the top and bottom are a total of $20 \mathrm{~cm}$ in thickness. This suggests that the tephra had been reworked by bottom current and biotubation, which likely diffused the tephra within the host sediments. Two size fractions $(63-150$ and $>150 \mu \mathrm{m})$ were separated and sampled for morphological and geochemical analyses.

The morphology of the glass shards was studied by the Riguku Scanning Electron Microscopy (SEM) at the Department of Geology, National Taiwan University. The major element compositions of the glass shards and mineral grains were determined using a JEOL JXA-8900R Electron Micro-Probe Analyzer (EPMA) at the Institute of Earth Sciences, Academia Sinica, Taiwan. Operating conditions were $15 \mathrm{kV}$, $10 \mathrm{nA}$ and were focused $(<1 \mu \mathrm{m})$ for accelerated voltage, probe current and beam diameter. The data were processed using the ZAF correction routine. Trace elements and REE were determined by Inductively Coupled Plasma-Mass Spectrometry (ICP-MS) using a Perkin-Elmer Elan-6000 spectrometer at the Guangzhou Institute of Geochemistry, Chinese Academy of Science, and this had good stability ranging within $\sim 5 \%$ variation (Liu et al., 1996).

\section{Glass morphology}

An extensive SEM study was performed on the large $(>150 \mu \mathrm{m})$ and small $(63-150 \mu \mathrm{m})$ grains of ash samples to examine the morphology of the glass shards. Figs. $3 \mathrm{~A}$ and $\mathrm{B}$ show the shards that have predominantly bubble-wall morphologies. Minor elongated vesicles of pumice fragments also occur. These morphologic characteristics are very similar to that of the glass shards of the YTT in the Indian Ocean and the Bay of Bengal (Rose and Chesner, 1987).

\section{Geochemistry}

To characterize and correlate the tephra bed in the SCSB, major and trace elements on fresh glass shards and major elements on minerals (Tables 1 and 2) were obtained. The glass samples were immersed in a $4 \mathrm{~N}$ acid and vibrated for $30 \mathrm{~min}$ in ultrasonic cleaner. 
Table 1

Microprobe analyses of glass shards and minerals of the tephra layer in IMAGES MD972151 core from the South China Sea Basin

\begin{tabular}{|c|c|c|c|c|c|c|}
\hline & \multicolumn{3}{|c|}{ Tephra in the South China Sea Basin (IMAGES-MD972151) } & \multicolumn{3}{|l|}{ Youngest Toba Tuff ${ }^{\mathrm{a}}$} \\
\hline & Glass $\pm 1 \sigma(n=15)$ & Amphibole $\pm 1 \sigma(n=6)$ & Biotite $\pm 1 \sigma(n=5)$ & Glass $^{\mathrm{b}}$ & Amphibole $^{c}$ & Biotite $^{\mathrm{d}}$ \\
\hline $\mathrm{SiO}_{2}$ & $76.08 \pm 0.40$ & $42.57 \pm 1.46$ & $35.77 \pm 0.19$ & 78.12 & 43.66 & 35.13 \\
\hline $\mathrm{TiO}_{2}$ & $0.06 \pm 0.03$ & $1.48 \pm 0.11$ & $4.14 \pm 0.11$ & 0.04 & 1.17 & 3.51 \\
\hline $\mathrm{Al}_{2} \mathrm{O}_{3}$ & $12.25 \pm 0.21$ & $9.12 \pm 1.02$ & $14.13 \pm 0.13$ & 12.04 & 8.14 & 12.95 \\
\hline $\mathrm{FeO}^{\mathrm{e}}$ & $0.85 \pm 0.05$ & $20.74 \pm 0.87$ & $22.99 \pm 0.36$ & 1.02 & 21.28 & 22.78 \\
\hline $\mathrm{MnO}$ & $0.06 \pm 0.05$ & $0.95 \pm 0.23$ & $0.37 \pm 0.18$ & 0.07 & 1.14 & 0.51 \\
\hline $\mathrm{MgO}$ & $0.04 \pm 0.02$ & $8.97 \pm 1.03$ & $9.75 \pm 0.19$ & 0.15 & 8.30 & 8.83 \\
\hline $\mathrm{CaO}$ & $0.72 \pm 0.08$ & $10.88 \pm 0.07$ & $-{ }^{\mathrm{f}}$ & 0.62 & 10.47 & 0.01 \\
\hline $\mathrm{Na}_{2} \mathrm{O}$ & $1.41 \pm 0.11$ & $1.08 \pm 0.11$ & $0.29 \pm 0.05$ & 2.68 & 1.80 & 0.35 \\
\hline $\mathrm{K}_{2} \mathrm{O}$ & $4.37 \pm 0.18$ & $0.92 \pm 0.07$ & $9.46 \pm 0.05$ & 5.20 & 0.92 & 8.64 \\
\hline $\mathrm{P}_{2} \mathrm{O}_{5}$ & $-{ }^{\mathrm{f}}$ & $-{ }^{\mathrm{f}}$ & $-{ }^{f}$ & 0.01 & & \\
\hline Total & 95.84 & 96.71 & 96.90 & 99.95 & 96.88 & 92.71 \\
\hline${ }^{87} \mathrm{Sr} /{ }^{86} \mathrm{Sr}^{\mathrm{g}}$ & $0.71372 \pm 2$ & & $0.71785 \pm 5$ & $0.71333-0.71521^{\mathrm{h}}$ & & \\
\hline $\begin{array}{l}{ }^{143} \mathrm{Nd} /{ }^{144} \mathrm{Nd} \\
\mathrm{Nd}^{\mathrm{i}}\end{array}$ & $\begin{aligned} 0.51218 & \pm 1 \\
& -9.0\end{aligned}$ & & $\begin{aligned} 0.51214 & \pm 3 \\
& -9.8\end{aligned}$ & $0.51220^{\mathrm{h}}$ & & \\
\hline $\begin{array}{l}\text { a Chemical } \\
\text { b XRF data } \\
{ }^{\text {c }} \text { EPMA dc } \\
{ }^{\text {d }} \text { EPMA dc } \\
\text { e All Fe as } \\
{ }^{\mathrm{f}} \text { Under the } \\
{ }^{\mathrm{g}} \text { Normaliz } \\
{ }^{\mathrm{h}} \text { Isotopic c } \\
{ }^{\mathrm{i}} \mathrm{Normaliz} \\
{ }^{143} \mathrm{Nd} /{ }^{144} \mathrm{Nd}\end{array}$ & $\begin{array}{l}\text { data from Chesner }(199 \\
\text { analyses normalized to } \\
\text { a; sample number is } 94 \\
\text { a; sample number is } 94 \\
\mathrm{Fe}^{+2} \text { except that in the } \\
\text { detected limit. } \\
\text { d to }{ }^{88} \mathrm{Sr} /{ }^{86} \mathrm{Sr}=0.1194 \\
\text { ata of all Toba tuff sam } \\
\text { d to }{ }^{146} \mathrm{Nd} /{ }^{144} \mathrm{Nd}= \\
0.511845 .\end{array}$ & $\begin{array}{l}\text { ). } \\
100 \% \text {, sample number is } 94 \\
15-3 \text {. } \\
15-3 \text {. } \\
\text { ass of the YTT, where } \mathrm{Fe} \text { a } \\
\text { reproducibility }(2 \sigma)= \pm 0.0 \\
\text { les from Chesner }(1988) \text {. } \\
.7219 ; \quad \epsilon \mathrm{Nd}=\left[\left({ }^{143} \mathrm{Nd} /{ }^{144}\right.\right.\end{array}$ & $\begin{array}{l}\text { 5-G. } \\
\mathrm{Fe}^{+3} \cdot \\
004 ; \mathrm{NBS} 987{ }^{87} \mathrm{Sr} /{ }^{86} \mathrm{~S}, \\
\text { dd) } / 0.51264-1] \times 10,\end{array}$ & $\begin{array}{l}=0.710226 \\
00 ; \quad \text { reproducibility }\end{array}$ & $(2 \sigma)= \pm 0.5 \epsilon \mathrm{Nd}$ & UCSD \\
\hline
\end{tabular}

They were then checked under binocular optical microscope to assess carbonate and silica contamination. All glass analyses totalled ca. $94.87-96.48 \%$, with the deficiency mainly due to secondary hydration; thus, the analyses were recalculated to $100 \%$ for comparative purposes.

Fifteen glass shards from different size fractions, five biotite and six amphibole grains (Table 1) were analyzed. All of the glass shards are rhyolitic with a narrow range and high contents of $\mathrm{SiO}_{2}$ (78.89$79.92 \mathrm{wt} \%)$, high- $\mathrm{K}_{2} \mathrm{O}(>4.28 \mathrm{wt} \%)$ and low- $\mathrm{Na}_{2} \mathrm{O}$ $(<1.58 \mathrm{wt} \%)$. Other diagnostic oxides also showed similar concordance with the narrow range of $\mathrm{SiO}_{2}$, e.g. $\mathrm{Al}_{2} \mathrm{O}_{3}, 12.51-13.04 \mathrm{wt} \%, \mathrm{FeO}, 0.81-0.94 \mathrm{wt} \%$, and $\mathrm{CaO}, 0.58-0.88 \mathrm{wt} \%$ (Table 1). These data (Table 1 and Fig. 4A) show significant differences from the tephra found in the north SCSB (Yang and Fan, 1990; Wang et al., 1992). However, they are very similar to the glass analyses reported for the proximal ignimbrite and distal tephra of the YTT (Chesner and Rose, 1991), for the tephra in the Ocean Drilling Program (ODP) site 758 that was correlated with the YTT (Dehn et al., 1991), and for the glass shards from the Central Indian Basin, Indian continent and Malaysia that were also correlated with the YTT (Pattan et al., 1999). Minor differences among the data here and these of the EPMA from the literature result from differing instrumental conditions, for example the higher $\mathrm{SiO}_{2}$ and lower $\mathrm{Na}_{2} \mathrm{O}$ contents in this study. The lower $\mathrm{Na}_{2} \mathrm{O}$ values are probably due to Na volatilization loss under the electron beam.

Biotite occurs as phenocryst in minor constituents $(<5 \%)$ in the SCSB tephra bed and exhibits tabular form. Chemical analyses show very little compositional variation and have magnesium numbers $(\mathrm{Mg} /$ $\mathrm{Mg}+\mathrm{Fe}$, all $\mathrm{Fe}$ as $\mathrm{Fe}^{2+}$ ) of $0.240-0.247$, which are a little lower than those of the Toba biotite from proximal ignimbrite (0.35-0.46) (Chesner, 1988). 
Table 2

Trace element data of glass shards of the tephra layer in IMAGES MD972151 core from the South China Sea Basin

\begin{tabular}{|c|c|c|c|c|c|c|}
\hline \multirow[b]{2}{*}{ Samples: } & \multicolumn{2}{|c|}{ Glass shards in South China Sea Basin } & \multicolumn{4}{|c|}{ Youngest Toba Tuff $^{\mathrm{a}}$} \\
\hline & MD51L $\mathrm{L}^{\mathrm{b}}$ & MD51S ${ }^{c}$ & Toba caldera $^{\mathrm{d}}$ & Malaysia $^{\mathrm{e}}$ & Indian Ocean $^{\mathrm{f}}$ & India $^{g}$ \\
\hline $\mathrm{Rb}$ & 187 & 194 & 265 & 240 & 247 & 223 \\
\hline $\mathrm{Sr}$ & 37 & 51 & 28 & 36 & 42 & 46 \\
\hline Y & 34 & 36 & 39 & 32 & 30 & 31 \\
\hline $\mathrm{Zr}$ & 74 & 74 & 73 & 75 & 81 & 79 \\
\hline $\mathrm{Nb}$ & 16.0 & 16.8 & 12.2 & 16.4 & 15.3 & 13.0 \\
\hline Cs & 7.20 & 7.58 & 9.51 & 7.52 & 8.51 & 7.44 \\
\hline $\mathrm{Ba}$ & 362 & 366 & 117 & 236 & 370 & 374 \\
\hline $\mathrm{La}$ & 27.80 & 27.07 & 20.35 & 21.35 & 27.25 & 26.16 \\
\hline $\mathrm{Ce}$ & 56 & 55 & 40 & 42 & 53 & 49 \\
\hline $\operatorname{Pr}$ & 6.17 & 6.13 & 4.92 & 4.73 & 5.82 & 5.45 \\
\hline $\mathrm{Nd}$ & 22.0 & 22.1 & 18.2 & 17.0 & 20.3 & 19.3 \\
\hline $\mathrm{Sm}$ & 4.37 & 4.56 & 4.21 & 3.63 & 4.18 & 4.29 \\
\hline $\mathrm{Eu}$ & 0.38 & 0.44 & 0.30 & 0.36 & 0.60 & 0.44 \\
\hline $\mathrm{Gd}$ & 4.47 & 4.73 & 4.92 & 4.72 & 5.72 & 4.15 \\
\hline $\mathrm{Tb}$ & 0.70 & 0.77 & 0.92 & 0.82 & 0.86 & 0.73 \\
\hline Dy & 4.49 & 4.82 & 6.25 & 5.46 & 4.41 & 4.91 \\
\hline Ho & 0.97 & 1.04 & 1.35 & 1.16 & 1.03 & 1.09 \\
\hline $\mathrm{Er}$ & 2.93 & 3.09 & 3.90 & 3.59 & 3.07 & 3.45 \\
\hline $\mathrm{Tm}$ & 0.52 & 0.52 & 0.77 & 0.64 & 0.56 & 0.51 \\
\hline $\mathrm{Yb}$ & 3.61 & 3.78 & 4.88 & 3.90 & 3.82 & 3.64 \\
\hline $\mathrm{Lu}$ & 0.55 & 0.60 & 0.88 & 0.67 & 0.63 & 0.63 \\
\hline $\mathrm{Hf}$ & 2.79 & 2.86 & 3.42 & 3.12 & 3.23 & 3.39 \\
\hline Ta & 1.77 & 1.88 & 1.15 & 1.59 & 1.90 & 1.15 \\
\hline Th & 30.3 & 31.6 & 30.3 & 25.4 & 29.7 & 27.5 \\
\hline $\mathrm{U}$ & 5.63 & 5.90 & 6.04 & 4.82 & 5.39 & 4.97 \\
\hline
\end{tabular}

${ }^{a}$ Chemical data fromWestgate et al. (1998).

b Sample MD51L: size $>150$.

c Sample MD51S: size $=63 \sim 150$.

${ }^{\mathrm{d}}$ ICP-MS data; sample number is UT1298.

e ICP-MS data; sample number is UT778.

${ }^{f}$ CP-MS data; sample number is UT1363.

${ }^{g}$ ICP-MS data; sample number is UT1299.

Nevertheless, the plot of $\mathrm{MgO}$ versus $\mathrm{TiO}_{2}$ shows that the biotite from the SCSB is similar to that of the YTT (Table 1, Fig. 4B).

Amphibole also occurs as phenocryst in minor constituents $(<1 \%)$ in the tuff bed of the SCSB, varying in form from sub- to euhedral grains. Chemical analyses show the amphibole are calcic and, using the nomenclature of Leake (1978), most can be classified as ferro-edenitic hornblende. The plots of major elements show that the amphiboles have little compositional variation and fall into the YTT field (Table 1, Fig. 4C).

Two fresh glass samples of different size fractions (63-150 and $>150 \mu \mathrm{m})$ were separated and sampled from the tephra layer for trace and Rare Earth Element (REE) analyses using the ICP-MS. The results demonstrate that both samples are very similar in trace elements and REE composition (Table 2 and Fig. 5). Characteristics of the glass shards are the enrichment of Large Ion Lithophile Elements (LILE) and Light Rare Earth Elements (LREE), and the depletion of $\mathrm{Ba}, \mathrm{Sr}, \mathrm{Ta}$ and $\mathrm{Nb}$ (Table 2). Also displayed is the characteristic of a negative Eu-anomaly in the REE pattern (Fig. 5). The compositions of trace elements and REE pattern diagrams also illustrate that the glass shards from the SCSB are similar to those of the YTT.

Glass shards and biotite were analyzed for $\mathrm{Sr}$ 

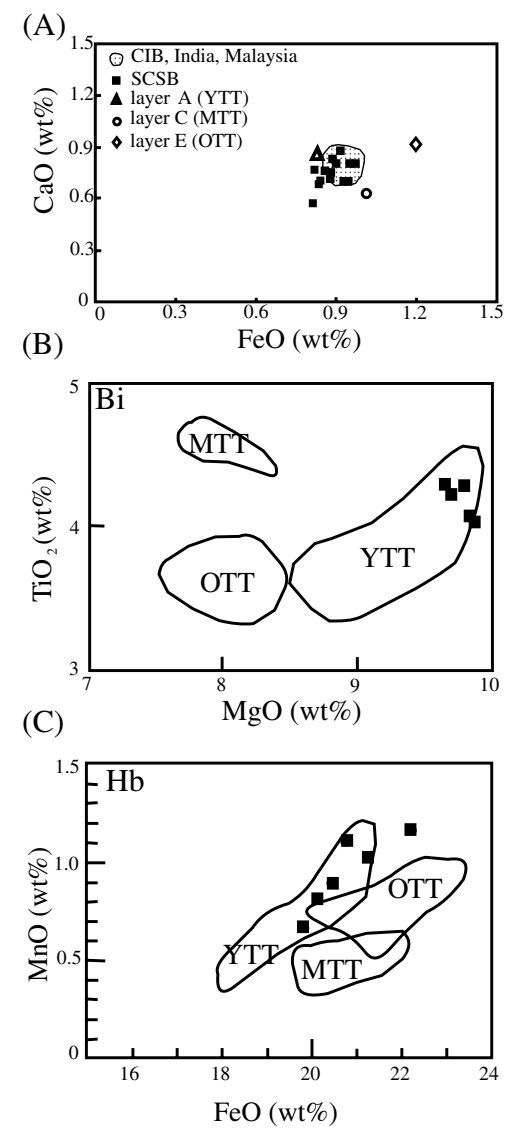

Fig. 4. (A) Composition of glass from core MD972151 in the SCSB compared to the composition of distal YTT found in the Central Indian Basin south of the equator (Pattan et al., 1999), India and Malaysia (Shane et al., 1995), and tephra layers A, C and E in ODP 758 (Dehn et al., 1991). Layer A: Youngest Toba; layer C: Middle Toba; layer E: Oldest Toba. (B) Composition of biotite from core MD972151 in the SCSB plots in the biotite variation diagrams of Toba Tuffs (Chesner, 1988). (C) Composition of amphibole from core MD972151 in the SCSB plots in the amphibole variation diagrams of Toba Tuffs (Chesner, 1988). YTT: Youngest Toba Tuff; MTT: Middle Toba Tuff; OTT: Oldest Toba Tuff.

isotopic composition (Table 1). The ${ }^{87} \mathrm{Sr} /{ }^{86} \mathrm{Sr}$ values of the glass shards and biotite fragments are $0.71372 \pm 0.00002$ and $0.71785 \pm 0.00005$, respectively. These figures are similar to the $\mathrm{Sr}$-isotopic value $(>0.712)$ of volcanic rocks from the Toba caldera (Whitford, 1975; Chesner, 1988), but they differ significantly from the lower values of volcanic rocks from the Philippine arc $(<0.705)$ (Knittel et al., 1988; Defant et al., 1989; Chen et al., 1990) and the eastern Indonesian arc (0.704-0.709) (Whitford and Jerek, 1979; Whitford et al., 1979).

\section{Discussion and conclusions}

Many tephra layers have been found in the Quaternary deep-sea sediments of the SCSB (Yang and Fan, 1990; Wang et al., 1992; Wiesner et al., 1995). They have generally been thought to be from the east, the Luzon and Bicol arc volcanoes in the Philippines, because the prevalent winds around the equator are westward (Kennett, 1981). However, it could be argued that the potential sources of the tephra in the SCSB were in the south, the Indonesian arc volcanoes and the local intra-basinal submarine volcanoes of the SCSB. To determine that the actual source, the chemical compositions of the glasses are required (e.g. Westgate and Gorton, 1981).

The tephra at around the $15.63 \mathrm{~m}$ depth of core MD972151 in the SCSB is characterized by fresh, bubble-wall glass shards suggesting that it was derived from fallout ashes. The analyses of the glass shards presented here reveal high total alkali contents and high ${ }^{87} \mathrm{Sr} /{ }^{86} \mathrm{Sr}$ values typical of high-SiO $\mathrm{S}_{2}$ rhyolites. Additionally, they display compositional uniformity suggestive of a single eruptive event. The volcanic rocks with high ${ }^{87} \mathrm{Sr} /{ }^{86} \mathrm{Sr}$ values $(>0.713)$ around the SCSB only occur in Western Indonesian arc volcanoes, especially the Toba ignimbrite (Whitford, 1975). Thus, the tephra layer at $15.63 \mathrm{~m}$ depth of core MD972151 in the SCSB may well be from the eruption of Toba caldera.

The interval of depth $15.58-15.63 \mathrm{~m}$ in core MD972151 is located between the oxygen isotopic event 5.1 (79.3 ka) and event 4.22 (64.1 ka) (Fig. 2). This stratigraphic age of the tephra layer is consistent with correlation to the YTT eruption, and it is seen to fall within the range of radimetric dates, 73,00075,000 years BP (Ninkovich et al., 1978; Chesner and Rose, 1991) or the ice-core dated age, 71,000 \pm 5000 years B.P. (Zielinski et al., 1996) previously reported. Furthermore, the geochemical characteristics of the glass shards examined here display elemental contents typical of rhyolites. Their compositions are an excellent match for glasses of the YTT in terms of plots of $\mathrm{CaO}$ versus $\mathrm{FeO}$ (Fig. 4A), biotite and hornblende chemistry (Fig. 4B and 4C) and the REE 


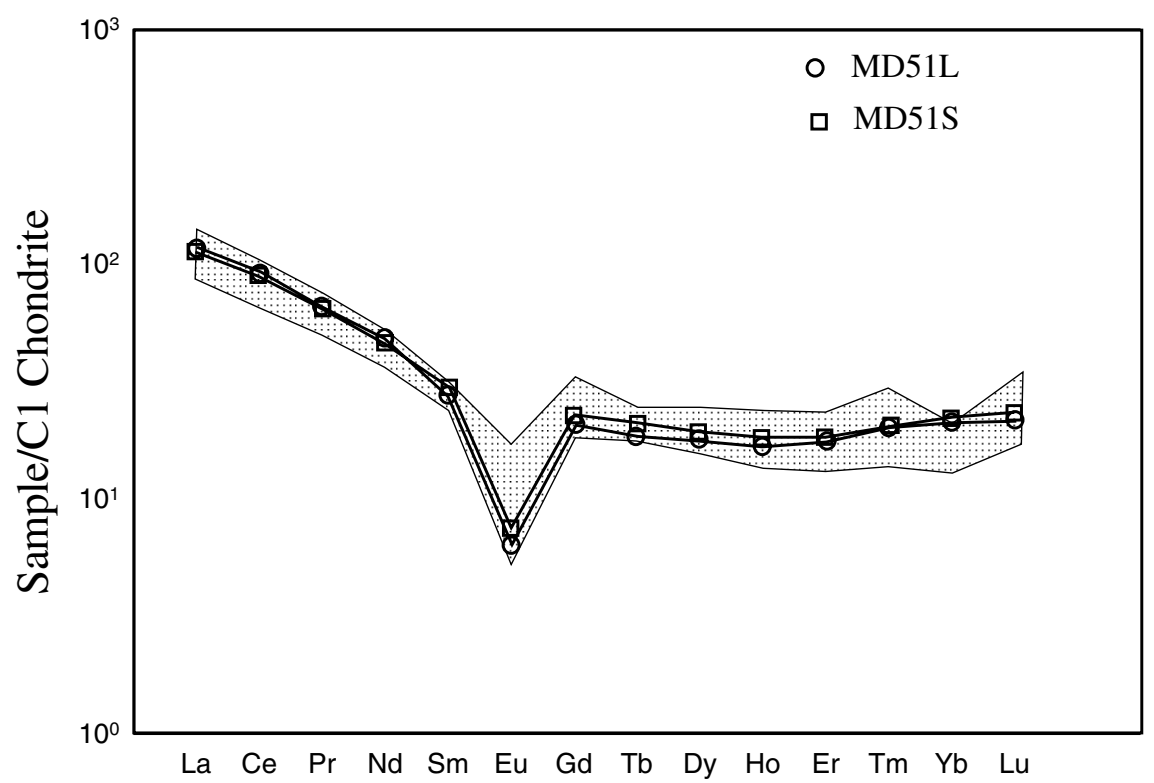

Fig. 5. Chondrite-normalized (Nakamura, 1974) rare-earth element composition of glass in core MD972151 of the SCSB. Shaded area is the compositional range of the distal YTT found in India, Malaysia and tephra layers A, C and E in ODP 758 (Westgate et al., 1998).

pattern (Fig. 5). In addition, the bubble-wall platy morphology of the shards resembles that of the distal tuff of the YTT found in cores of the Bay of Bengal and Indian Ocean (Rose and Chesner, 1987) and in India (Shane et al., 1995). Thus, the tephra layer occurring in core MD972151 of the SCSB is likely to be from the YTT eruption, the largest eruption in the Quaternary.

The previously estimated volume for YTT is about 2500 3000 km ${ }^{3}$ (Rose and Chesner, 1987). In addition, abundant glass shards of the YTT have been found in the central Indian Ocean Basin south of the equator, which greatly extends the known fallout distribution of coarse shards $(>63 \mu \mathrm{m})$ some $1500 \mathrm{~km}$ to the south suggesting that earlier fallout volume estimates represent a minimum (Pattan et al., 1999).

The new finding of the eastern dispersal of the YTT in the SCSB, which the authors recognized here, extends the previously known fallout zone some $1500 \mathrm{~km}$ to the northeast. In fact, at least $1 \%$ of the Earth's surface could have been affected by direct fallout. This indicates that the volume of the YTT eruption previously reported was much underestimated. Unfortunately, so far just one site with the
YTT glass shards in the SCSB was identified which does allow any comprehensive estimation of the actual fallout volume.

Distribution of tephra erupted from the YTT has been found throughout Malaysia, the Bay of Bengal, Indian Ocean Basin north of the equator (Ninkovich, 1979; Rose and Chesner, 1987; Dehn et al., 1991) and over much of the Indian subcontinent to the Arabian Sea, more than $3000 \mathrm{~km}$ from the source (Shane et al., 1995; Schulz et al., 1998). Furthermore, a relatively new occurrence of the YTT in abyssal sedments of the Central Indian Basin south of the equator has been identified (Pattan et al., 1999). All of the known fallout dispersal has suggested that the prevalent winds were westward during the YTT eruption. The tephra of the YTT in the SCSB, identified in this study greatly extends the known fallout distribution of coarse shards $(>63 \mu \mathrm{m})$ some $1500 \mathrm{~km}$ to the northeast. This distribution pattern suggests that the tephra of the YTT was dispersed not only by the prevalent westward winds but also by northeastward winds. Thus, a co-ignimbrite eruption with a different wind field, namely the upper tropospheric and stratospheric westward winds and the monsoon with prevalent northeastward winds in the summer, have recently 
been proposed to explain the whole fallout distribution of YTT coarse shards (Chen et al., 2000, unpublished result). This unique tephra layer offers a key bed for marine chronological correlation in the SCSB.

It has been reported that the huge amounts of volcanic aerosols and fine particles injected into the stratosphere by the YTT eruption may have enhanced the rate of climate change (Rampino and Self, 1993). However, the global climatic impact by the YTT huge eruption has yet to be clarified. The paleoclimatic variation immediately after the Toba eruption, as derived from the records of the GISP2 Greenland ice core, showed a pronounced cooling of 1000 years, which ended the warm period of the interstadial (IS) 20 (Zielinski et al., 1996). It must be noted, though, that the high-resolution planktonic oxygen isotopic record around the Toba eruption in core MD972151 of the SCSB shows a significant positive excursion $(>0.6 \%$ ) following the event, corresponding to the stadial between instadials (IS) 19 and (IS) 20, and the $\mathrm{U}_{37^{\mathrm{K}^{\prime}}}$-derived sea surface temperatures dropped by only $1^{\circ} \mathrm{C}$ (Lee et al., 1999b). Thus, the impact of the YTT huge eruption on the global climate needs further investigation.

\section{Acknowledgements}

The authors appreciate the assistance of the Captain and all cruise members on the RV Marion Dufresne during the IMAGES III cruise in June 1997. Part of the IMAGES III-IPHIS cruise over the South China Sea (Leg III) was supported by the National Science Council, Republic of China. The tephra project is supported under grant NSC88-2116-M-001-022.

\section{References}

Chen, C.H., Lee, T., Shieh, Y.N., Chen, C.H., Mertzman, A., 1990. $\mathrm{Nd}-\mathrm{Sr}-\mathrm{O}$ isotopic evidence for source contamination and unusual mantle components under the Luzon arc. Geochim. Cosmochim. Acta 54, 2473-2483.

Chen, M.T., Beaufort, L., et al., 1998. Exploring the Quaternary variability of the East Asia monsoon, Kuroshio current, and the Western Pacific Warm Pool system: high resolution investigation of paleooceanography from the IMAGES III (MD106)IPHIS Cruise. Terres. Atmos. Oceanic Sci. 9, 129-142.

Chesner, C.A., 1988. The Toba tuffs and caldera complex, Sumatra, Indonesia: insight into magma bodies and eruptions. $\mathrm{PhD}$ thesis, Michigan Technological University, Houghton.
Chesner, C.A., 1998. Petrogenesis of the Toba tuff, Sumatra, Indonesia. J. Petrol. 39, 397-438.

Chesner, C.A., Rose, W.I., 1991. Eruptive history of Earth's largest Quaternary caldera (Toba Indonesia) clarified. Geology 19, 200-203.

Defant, M.J., Jacques, D., Maury, R.C., Boer, J.D., Joron, J.L., 1989. Geochemistry and tectonic setting of the Luzon arc, Philippines. Geol. Soc. Amer. Bull. 101, 663-672.

Dehn, J., Farrel, J.W., Schmincke, H.-U., 1991. Neogene tephrochronology from site 758 on Ninety East Ridge: Indonesian arc volcanism of the past 5 Ma. Proc. ODP, Sci. Results 121, 273-295.

Diehl, J.F., Onstott, T.C., Chesner, C.A., Knight, M.D., 1987. No short reversals of Brunhes age recorded in the Toba Tuffs, north Sumatra, Indonesia. Geophys. Res. Lett. 14, 753-756.

Kennett, J.P., 1981. Marine tephrochronology. In: Emiliani, C. (Ed.). The Sea, vol. 7. Wiley, New York, pp. 1373-1436.

Knittel, U., Defant, M.J., Raczek, I., 1988. Recent enrichment in the source region of arc magmas from Luzon island, Philippines: $\mathrm{Sr}$ and $\mathrm{Nd}$ isotopic evidence. Geology 16, 73-76.

Leake, B.E., 1978. Nomenclature of amphiboles. Am. Miner. 63, 1023-1052.

Lee, M.Y., Wei, K.Y., Chen, Y.G., 1999. High resolution oxygen isotope stratigraphy for the last 150,000 years in the southern South China Sea: Core MD972151. Terres. Atmos. Oceanic Sci. 10, 239-254.

Lee, M.Y., Wei, K.Y., Chen, C.H., Song, S.R., Huang, C.Y., 1999. New Occurrence of Toba Tephra in the South China Sea and the possible climate impact induced by the Mega-eruption (Abstract, 1999 AGU Fall meeting).

Liu, Y., Liu, H., Li, X.H., 1996. Simultaneous and precise determination of 40 trace elements in rock samples. Geochimica 25, 552-558 (in Chinese).

Nakamura, N., 1974. Determination of REE, Ba, Fe, Mg, Na, and K in carbonaceous and ordinary chondrites. Geochim. Cosmochim. Acta 38, 757-775.

Ninkovich, D., 1979. Distribution, age and chemical composition of tephra layers in deep-sea sediments off West Indonesian. J. Volcanol. Geotherm. Res. 5, 67-86.

Ninkovich, D., Sparks, R.S.J., Ledbetter, M.T., 1978. The exceptional magnitude and intensity of the Toba eruption, Sumatra: An example of the use of deep-sea tephra layers as a geological tool. Bull. Volcanol. 41, 286-298.

Pattan, J.N., Shane, P., Banakar, V.K., 1999. New occurrence of Youngest Toba Tuff in abyssal sediments of the Central Indian Basin. Mar. Geol. 155, 243-248.

Rampino, M.R., Self, S., 1992. Volcanic winter and accelerated glaciation following the Toba super-eruption. Nature 359, 50-52.

Rampino, M.R., Self, S., 1993. Climate-volcanism feedback and the Toba eruption of $\sim 74,000$ years ago. Quat. Res. 40, 269-280.

Rose, W.I., Chesner, C.A., 1987. Dispersal of ash in the great Toba eruption. Geology 15, 913-917.

Schulz, H., von Rad, U., Erlenkeuser, H., 1998. Correlation between Arabian Sea and Greenland climate oscillations of the past 110,000 years. Nature 393, 54-57.

Shane, P., Westgate, J., Williams, M., Korisettar, R., 1995. New geochemical evidence for the Youngest Toba Tuff in India. Quat. Res. 44, 200-204. 
Wang, H., Zhou, F., Jian, J., 1992. Volcanic clasts in the periplatform carbonate ooze near the Zhongsha Islands and their bearing on the paleo-environment (in Chinese with English abstract). In: Ye, Z., Wang, P. (Eds.). Contributions to Late Quaternary Paleoceanography of the South China Sea, Qingdao Ocean University, Qingdao, pp. 42-54.

Westgate, J.A., Gorton, M.P., 1981. Correlation techniques in tephra studies. In: Self, S., Sparks, R.S.J. (Eds.). Tephra Studies, D. Reidel, Dordrecht, pp. 73-94.

Westgate, J., Shane, P., Pearce, N., Perkins, W., Korisettar, R., Chesner, C., Williams, M., Acharyya, S., 1998. All Toba tephra occurrences across Peninsular India belong to the 75,000 years B.P. eruption. Quat. Res. 50, 107-112.

Whitford, D.J., 1975. Strontium isotopic studies of the volcanic rocks of the Sunda arc, Indonesia, and their petrogenetic implications. Geochim. Cosmochim. Acta 39, 1287-1302.
Whitford, D.J., Jerek, P.A., 1979. Origin of late-Cenozoic lavas from the Banda arc, Indonesia: trace element and $\mathrm{Sr}$ isotope evidence. Contrib. Miner. Petrol. 68, 141-150.

Whitford, D.J., Nicholls, I.A., Taylor, S.R., 1979. Spatial variation in the geochemistry of Quaternary lavas across the Sunda arc in Java and Bali. Contrib. Miner. Petrol. 70, 341-356.

Wiesner, M.G., Wang, Y., Zheng, L., 1995. Fallout of volcanic ash to the deep South China Sea induced by the 1991 eruption of Mount Pinatubo (Philippines). Geology 23, 885-888.

Yang, Y., Fan, S., 1990. Research on volcanic sediments and origin of volcanic substance in the South China Sea during late Quaternary (in Chinese with English abstract). Tropical Oceanogr. 9, 52-60.

Zielinski, G.A., Mayewski, P.A., Meeker, L.D., Whitlow, S., Twicker, M.S., Taylor, K., 1996. Potential atmospheric impact of the Toba mega-eruption $\sim 71,000$ years ago. Geophys. Res. Lett. 23, 837-840. 